Article

\title{
Cryptosporidium and Giardia in Biogas Wastewater: Management of Manure Livestock and Hygiene Aspects Using Influent, Effluent, Sewage Canal Samples, Vegetable, and Soil Samples
}

\author{
Nguyen Thuy Tram ${ }^{1,+}$, Pham Duc Phuc ${ }^{2,+}$, Nguyen Hong Phi ${ }^{2}{ }^{\mathbb{D}}$, Le Thi Trang ${ }^{1}$, Tang Thi Nga ${ }^{1}$, \\ Hoang Thi Thu Ha ${ }^{1}$, Phung Dac Cam ${ }^{1}$, Tran Quang Canh ${ }^{3}$ and Panagiotis Karanis ${ }^{4,5, *(\mathbb{C}}$
}

check for updates

Citation: Tram, N.T.; Phuc, P.D.; Phi, N.H.; Trang, L.T.; Nga, T.T.; Ha, H.T.T.; Cam, P.D.; Canh, T.Q.; Karanis, P. Cryptosporidium and Giardia in Biogas Wastewater: Management of Manure Livestock and Hygiene Aspects Using Influent, Effluent, Sewage Canal Samples, Vegetable, and Soil Samples. Pathogens 2022, 11, 174. https://doi.org/10.3390/ pathogens11020174

Academic Editor: Staffan Svärd

Received: 27 December 2021

Accepted: 25 January 2022

Published: 27 January 2022

Publisher's Note: MDPI stays neutral with regard to jurisdictional claims in published maps and institutional affiliations.

Copyright: (c) 2022 by the authors. Licensee MDPI, Basel, Switzerland. This article is an open access article distributed under the terms and conditions of the Creative Commons Attribution (CC BY) license (https:// creativecommons.org/licenses/by/ $4.0 /)$.
1 Department of Bacteriology, National Institute of Hygiene and Epidemiology (NIHE), 1 Yersin, Hanoi 122000, Vietnam; ntt3@nihe.org.vn (N.T.T.); letrang1980@gmail.com (L.T.T.); tangngah@gmail.com (T.T.N.); htth@nihe.org.vn (H.T.T.H.); phungdaccam1@gmail.com (P.D.C.)

2 Center for Public Health and Ecosystem Research (CENPHER), Hanoi University of Public Health, 1A Duc Thang, Hanoi 122000, Vietnam; pdp@huph.edu.vn (P.D.P.); nhp@huph.edu.vn (N.H.P.)

3 Department of Medical Laboratory Science, Hai Duong Medical Technical University, 1 Vu Huu, Thanh Binh, Hai Duong 17000, Vietnam; canhhdt@gmail.com

4 Medical Faculty, University of Cologne, University Hospital, 50931 Cologne, Germany

5 Department of Basic and Clinical Sciences, Medical School, Anatomy Institute, University of Nicosia, Nicosia 2408, Cyprus

* Correspondence: karanis.p@unic.ac.cy

+ These authors made equal contributions to this manuscript.

\begin{abstract}
Cryptosporidium and Giardia are two water- and foodborne protozoan parasites that can cause diarrheal diseases. Poor microbial quality, sanitation conditions, and hygiene practices at exposure to biogas wastewater are important risk factors for human and animal infection. This study highlights the presence and level of both parasites in the environment in relation to biogas waste reuse in Vietnam. A total of 239 samples were collected from different types of samples in the studied districts in Bac Giang province in 2020 via direct immunofluorescent detection to study the occurrence of Cryptosporidium spp. and Giardia spp. (oo)cysts. Among the samples, Cryptosporidium was found in $19(7.9 \%)$ with concentration from $1.10^{4}$ to $3.10^{5}$ oocysts $/ 100 \mathrm{~mL}$, while Giardia in $40(16.7 \%)$ with concentration from $1.10^{4}$ to $2.10^{6}$ cysts $/ 100 \mathrm{~mL}$, respectively. In detail, the results show that the percentages of positive detection of Cryptosporidium spp. and Giardia spp. in influent, effluent, sewage canal, and vegetables were $13.1 \%(11 / 84), 6.0 \%(5 / 83), 15.4 \%(2 / 13)$ and $5.9 \%(1 / 17)$ and $26.2 \%(22 / 84), 7.2 \%(6 / 83), 7.7 \%(1 / 13)$ and $5.9 \%(1 / 17)$, respectively. The results show a trend of decreasing Cryptosporidium and Giardia densities, without statistical significance. Although these parasites decreased after biogas treatment, the remaining loads observed in biogas effluent can reach the watercourses and soil receiving it. Further investigations are needed to contribute to a general understanding of the risk of protozoan parasites, as well as strategies to control and reduce the contamination of environmental water sources and plants and reduce the burden of the pathogens in biogas wastewater in Vietnam.
\end{abstract}

Keywords: biogas wastewater; Giardia; Cryptosporidium; detection; Vietnam

\section{Introduction}

Agricultural production plays a leading role in Vietnam. Livestock and poultry production have been gradually changing in scale from household to farm. Along with the development of the livestock sector, biogas technology has helped livestock farmers in treating animal waste and providing clean energy to the community. Building and using biogas plants in livestock production are one of the effective solutions for managing large 
volumes of animal manure. Biogas technology minimizes the negative impact of pollution on the environment, reduces disease risks for humans, animals, and diminishes the risk of livestock waste in agricultural areas. At the same time, it contributes to the sustainable development of household husbandry and farming, the generation of clean energy sources, the improvement of livelihoods, and the enhancement of the quality of life for rural people, all of which are in line with the current development trend of the agricultural industry [1]. With these many proven benefits, biogas technology has become widespread throughout Asia and Vietnam.

The discharge of raw wastewater into the environment due to poor management and insufficient treatment of livestock manure is undoubtedly a contamination source of bacterial, fungal, viral, and protozoa pathogens. Among these parasites, Cryptosporidium spp. and Giardia spp., are transmitted through oocysts and cysts which are excreted in high numbers in the feces of infected hosts [2,3]. Consequently, raw water bodies, soils, and vegetables are subject to parasitic contamination. Moreover, (oo)cysts are resistant to environmental stresses, which makes their disposal using conventional methods and disinfection processes difficult [3]. Taking into consideration the low infective dose of these parasites, it has been suggested that exposure of wastewater could infer a health risk of protozoan infections [4]. As a result, these parasites are responsible for several outbreaks worldwide [5-9], causing them to be emerging and re-emerging targets of current research on food and waterborne parasites [10].

Several studies have identified high levels of Cryptosporidium and Giardia oo(cysts) in both treated and untreated wastewater from Wastewater Treatment Plants (WWTPs) [11-13]. An extended preliminary survey of biological treatment plants indicated that Cryptosporidium oocysts are found both in the input and the discharge of the biological treatment plants in Greece [14]. Findings from a study in Canada indicated that anaerobically digested biosolids can contain up to $10^{1}$ oocysts / $g$ of Cryptosporidium and $10^{2}$ cysts/g of Giardia [15].

The occurrence of the (oo)cysts of Cryptosporidium and Giardia in agricultural water and other aquatic environments is a globally acknowledged public health problem. An European surveillance of communicable disease consistently describes the occurrence of significant numbers of verified cases of cryptosporidiosis and giardiasis that are distributed across virtually all of the countries in and adjacent to Europe [16]. This highlight features of their presence and distribution that present a clear risk of waterborne transmission. In addition, this should dictate features of monitoring essentials to minimize risk through the effective management of watersheds and water treatment systems.

In Vietnam, household-scale anaerobic digesters from livestock manure are currently promoted for bioenergy production as they reduce odor and provide an effluent with a high fertilizer value that can be used to fertilize field, garden crops, and fishponds [17]. However, biogas effluents can pollute aquifers, crops, and surface water due to inadequate manure management. As a result, risks of environmental pollution are increased, and high incidences of giardiasis and cryptosporidiosis may be attributed to livestock waste. Two investigations [18,19] reported a high prevalence of protozoan parasites (Cryptosporidium, Cyclospora, Giardia) in environmental samples collected from farms and markets in Hanoi and Hanam, Vietnam. Detection of zoonotic species had confirmed the potential high risk of protozoan infection to those who have been exposed to wastewater, contaminated soil, water, and food. In a previous study, Le-Thi et al. in 2017 [20] estimated that the annual diarrhea risk caused by exposure to biogas effluent through irrigation activities ranges from 17.4 to $21.1 \%$ (E. coli O157:H7), 1.0 to $2.3 \%$ (G. lamblia), and 0.2 to $0.5 \%$ (C. parvum), while those caused through unblocking drains connected to biogas effluent tanks were $22 \%$ (E. coli O157:H7), 0.7\% (G. lamblia), and 0.5\% (C. parvum). Although studies in Vietnam have not found evidence of Cryptosporidium and Giardia clinical diseases among children with diarrhea [21-23], it is most likely that these parasites are widely distributed in these populations. A study on HIV positive humans found that the C. paroum human genotype infects three people in Vietnam [24]. Healthy people $(\mathrm{N}=2522)$ in north-western Vietnam had a surprisingly high prevalence of Giardia (4.1\%) [25]. Recently, a total of 2715 samples 
(2120 human diarrheal samples, 471 human non-diarrheal samples, and 124 animal stool samples) were collected from a community survey in an agricultural area in Vietnam. It was found that 15 samples (10 diarrheal samples, 2 non-diarrheal samples, and 3 animal stool samples) tested positive with Cryptosporidium and (23 animal stool samples, 8 human non-diarrheal samples, and 36 human diarrheal samples) with Giardia by PCR [26,27].

Considering the occurrence and contamination level of Cryptosporidium and Giardia (oo)cysts as well as hygiene aspects in the management of biogas wastewater, this study aimed to determine the occurrence and evaluate the levels of Giardia and Cryptosporidium (oo)cysts in pre- and post-biogas waste treatment that are used for agriculture activities in Vietnam. Obtaining data on the quality of biogas wastewater will provide a better understanding on the current sanitation of biogas plants, which are valuable information for further research on the intervention and assessment of human health risk of communities with biogas plants installation.

\section{Materials and Methods}

\subsection{Study Area}

Bac Giang province is located about $80 \mathrm{~km}$ east of Hanoi (population 1,841,000) (Figure 1). The Bac Giang livestock sector is developing to contribute to the provincial value of the agricultural sector in Vietnam. Pig farming is mainly located in Tan Yen, Lang Giang, Viet Yen, and Luc Ngan districts. Poultry is mainly concentrated in districts of Yen The, Tan Yen, Luc Ngan, Luc Nam, Hiep Hoa, and Lang Giang. Ducks are mainly raised in Lang Giang, Hiep Hoa, and Yen The districts. The total number of households raising chicken in Bac Giang province is 237,387, accounting for 83.7\% of agricultural production households and $63.47 \%$ of total rural households. Due to the strong development of livestock, changes have occurred in livestock production due to the establishment of large-scale farms. Along with the development of the livestock sector, biogas technology has helped livestock farmers in treating animal waste and providing clean energy to the community. Using biogas technology is an effective solution to the problems of supplying energy and reducing environmental pollution in the countryside. However, in Thai Binh and Bac Giang provinces, $43 \%$ of pig manure is used as biogas substrate, with $19 \%$ of the untreated and composted manure discharged into aquatic recipients and $17 \%$ of the biogas effluent discharged into rivers or canals [17]. In addition, many farmers discharge biogas effluent into the environment, e.g., the household garden, canals, lakes, and occasionally the public sewer system, as many farmers are not aware of the nutrient content and fertilizer value of biogas effluent. Hiep Hoa, Lang Giang, Yen The, and Viet Yen are the districts with the largest number of biogas plants in Bac Giang, accounting for nearly $70 \%$ of biogas plants built in the province. Most of the biogas plants have been built as KT1 and KT2 types (Figure 2) [1]. Therefore, the study was conducted in Lang Giang, Viet Yen, and Hiep Hoa districts. These districts are peri-urban areas of Bac Giang city. Biogas waste was used mainly for fruit tree, corn, and vegetable cultivation. The districts had more than $97 \%$ of farmers. There was a mix between farming families exposed to biogas wastewater and those who were not exposed, depending on the installation of a biogas plant at the households.

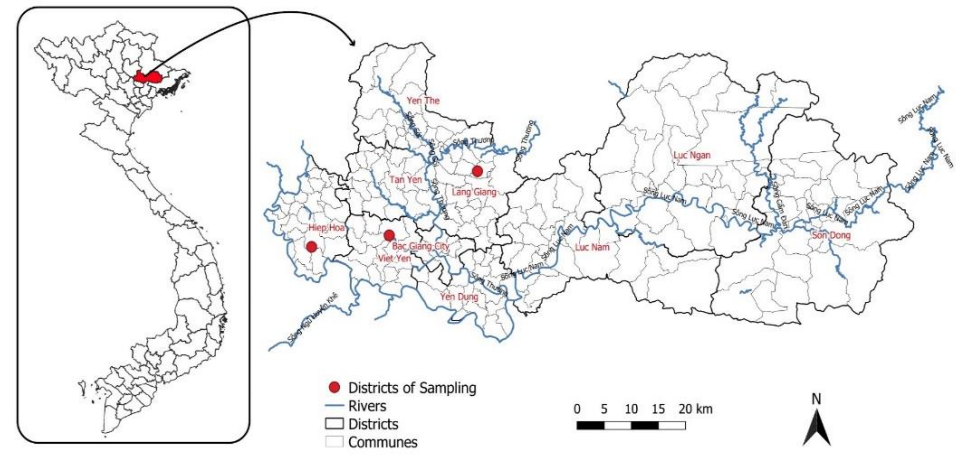

Figure 1. Map of Bac Giang province, where the red dots are illustrated for districts of sampling. 


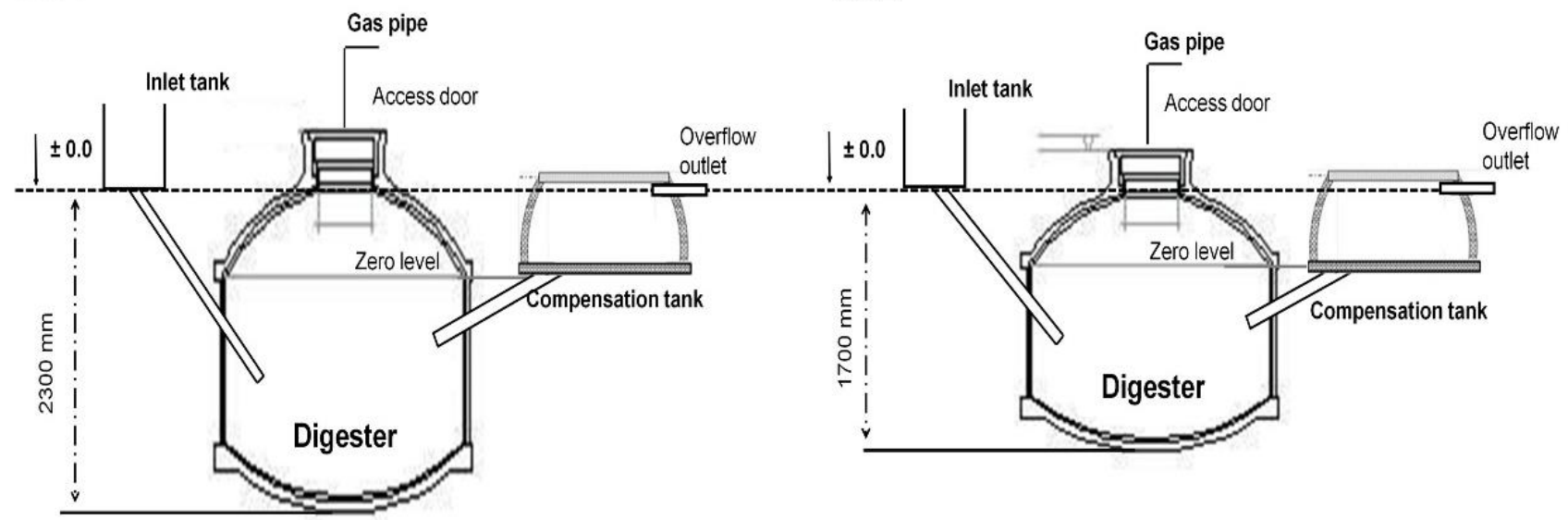

Figure 2. Schematic drawing of biogas plant types (KT1 and KT2) used by farmers in Bac Giang province).

\subsection{Study Population}

Three hundred and ninety-four households (135 households in Lang Giang, 172 households in Viet Yen, and 87 households in Hiep Hoa) were randomly selected from an official list of households from each district. Households that had not installed a biogas plant and were not involved in agriculture at all were excluded. All of the females and males with 15 years of age and above living in the selected households were included in the questionnaire interviews.

\subsection{Household Questionnaire}

A cross-sectional study was conducted from March through August 2020. The selected households were surveyed using a structural questionnaire administered to the head of the household or their partner. The extent of contact with biogas wastewater was assessed for all of the individuals ( $\geq 15$ years of age and living in the study area at the time of the study). The extent of contact included the status of any contact with biogas wastewater and the frequency of contact (hours per contact, days of contact per month etc.). This information was obtained from the person him/herself or from the main respondent of the household in the case that the person was absent at the time of the interview. The following information was also collected for each individual: Age, sex, occupation, educational level, types of agriculture production involved, and the use of protective measures during agricultural work. At the household level, information was obtained on household source and sanitation (hygienic status and biogas waste handling), livestock manure use practices in agriculture/horticulture, and personal hygiene behavior including hand washing practices [18].

\subsection{Sample Collection and Protozoan Parasitological Analyses}

A total of 239 samples including 84 influent samples, 83 effluent samples, 13 sewage canal samples, 21 pond/lake water samples, 21 soil samples, and 17 vegetables were collected from six locations. Samples were collected during the household survey between March through August 2020 (Figure 3). 

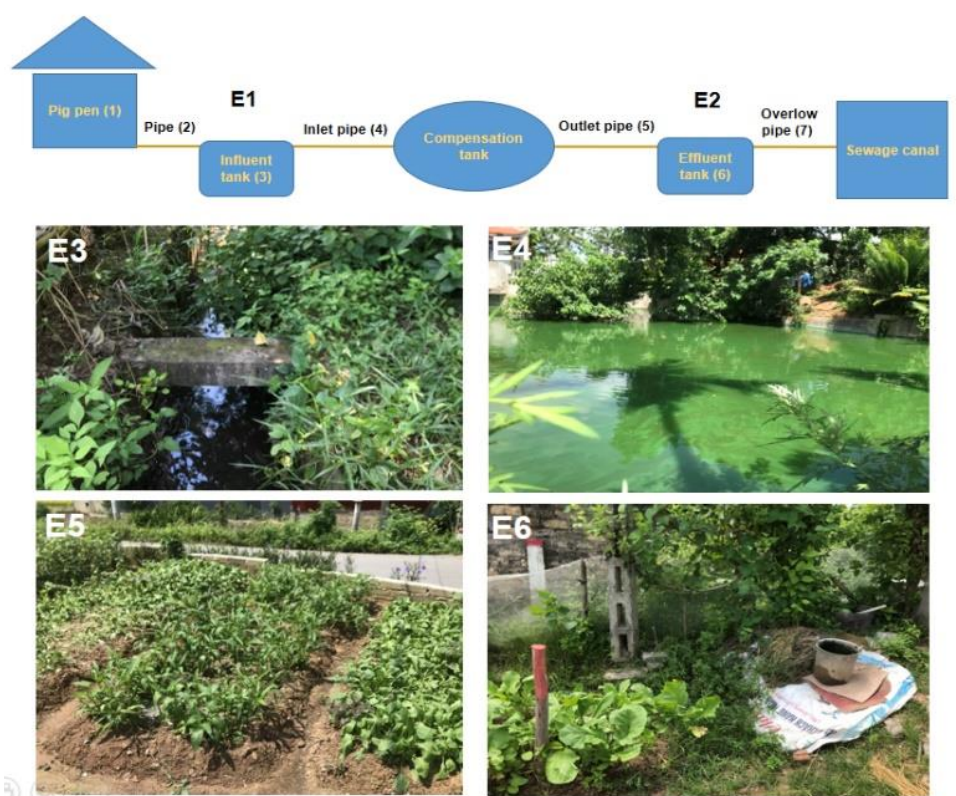

Figure 3. Schematic drawing of sampling locations (Source: Vu Van Tu and Nguyen Manh Hien). E1-Influent (composite sample of 2, 3, 4); E2-Effluent (composite sample of 5, 6, 7); E3-Sewage canal next to biogas plants and receiving both biogas and flush toilet wastewater; E4-Lake/pond in a close area of biogas plants; E5-Soil near biogas plants and receiving biogas waste; E6-Vegetables grown near biogas plants and receiving biogas waste for irrigation.

\subsubsection{Collection and Preparation of Influent, Effluent, and Sewage Canal Samples}

Influent samples were collected at the drain that receives both water and livestock waste from pig pen cleaning activities. Effluent samples were collected at the effluent tank, which was $20 \mathrm{~cm}$ in depth and situated in the center of biogas plant [21]. The effluent tank of the biogas plant is where the farmers collect effluent for irrigation of agriculture/horticulture. Sewage canal samples were collected at the open household drain that receives biogas effluent, wastewater, and other runoff flow. For sampling and concentration, composite samples consisting of three individual $50 \mathrm{~mL}$ samples were placed in a $50 \mathrm{~mL}$ sterile falcon tube [19]. All of the samples were stored in a cooling box and transported to the laboratory at the National Institute of Hygiene and Epidemiology (NIHE) in Hanoi on the day of sampling for further processing. Samples were analyzed according to a previously described method. Briefly, $10 \mathrm{~g}$ of composite waste samples was added to $90 \mathrm{~mL}$ of distilled water and homogenized for $30 \mathrm{~s}$ in a vortex mixer (Pulsifier ${ }^{\circledR}$, Filtaflex, Almonte, ON, Canada). Samples were concentrated by centrifugation followed by a flotation step where $10 \mathrm{~mL}$ of the pelleted sample was underlaid with $5 \mathrm{~mL}$ of flotation fluid (saturated $\mathrm{NaCl}$ solution with $500 \mathrm{~g}$ of glucose added per liter; diluted 1:1 with sterile distilled water to a final specific gravity of $1.13 \mathrm{~g} / \mathrm{mL}$ ), and centrifuged for $1 \mathrm{~min}$ at $100 \times \mathrm{g}$. All of the supernatant was transferred to a clean tube to remove larger debris. The sample was subsequently washed twice with sterile distilled water with centrifugation of $1540 \times g$ for $10 \mathrm{~min}$ to remove the remains of the flotation fluid before concentrating the sample volume to $2 \mathrm{~mL}[19,28]$.

\subsubsection{Collection and Preparation of Surface Water Samples}

Surface water samples (lake, pond or river), which were in close proximity to a biogas plant or received biogas wastewater runoff that was used for irrigation purposes, were collected (Figure 3). Composite water samples consisting of three individual $1 \mathrm{~L}$ samples were collected in sterile, wide-mouth, screw-capped $1 \mathrm{~L}$ bottles. All of the samples were stored in a cooling box and transported to the NIHE laboratory on the day of sampling. Further analysis was implemented by concentration and centrifugation followed by a 
flotation step with saturated $\mathrm{NaCl}$-glucose solution to attain the final volume of $2 \mathrm{~mL}$, as described above [19,28].

\subsubsection{Collection and Preparation of Vegetables and Soils}

Vegetables grown in household gardens and soils, which were close to a biogas plant or received biogas waste, were randomly collected. Two hundred grams of vegetables (stem and leaves) or soils were picked using sterile plastic bags. Then, the samples were stored in a cooling box and transported to NIHE on the day of sampling. Samples of $10 \mathrm{~g}$ of vegetables (stems and leaves) or $10 \mathrm{~g}$ of soils were washed with $90 \mathrm{~mL}$ of $0.01 \%$ TWEEN20 (Sigma-Aldrich, Merck, Darmstadt, Germany) in distilled water in a Pulsifier instrument (Pulsifier ${ }^{\circledR}$, Filtaflex, Almonte, ON, Canada). Samples were concentrated by centrifugation followed by a flotation step, where $10 \mathrm{~mL}$ of the pelleted sample was underlaid with $5 \mathrm{~mL}$ of flotation fluid (saturated $\mathrm{NaCl}$ solution with $500 \mathrm{~g}$ of glucose added per liter; diluted 1:1 with sterile distilled water to a final specific gravity of 1.13), and centrifuged for $1 \mathrm{~min}$ at $100 \times g$. All of the supernatant was transferred to a clean tube to remove larger debris The sample was subsequently washed twice with sterile distilled water to remove the remains of the flotation fluid before concentrating the sample volume to $2 \mathrm{~mL}[19,28]$.

\subsection{Enumeration of Cryptosporidium and Giardia (oo)cysts}

Ten microliters of the concentrated sample was microscopically examined. Oocysts and cysts were detected and identified in a $10 \mu \mathrm{L}$ solution $\left(20 \mu \mathrm{L}\right.$ Merifluor ${ }^{\circledR}$ Cryptosporidium/ Giardia kit (Meridian Bioscience, Inc., Newtown, OH, USA), $0.5 \mu \mathrm{L}$ DAPI (4',6-diaminodino2-phenyl-indol, Sigma-Aldrich, St. Louis, MO, USA), $2 \mathrm{mg} / \mathrm{mL}$ and $80 \mu \mathrm{L}$ PBS $1 \times$ ) mixed with a $10 \mu \mathrm{L}$ mounting buffer. Giardia and Cryptosporidium (oo)cysts were quantified using epifluorescent microscopy (Nikon, Eclipse E600) with a magnification of 300-800×. A blue filter (excitation, $480 \mathrm{~nm}$; emission, $520 \mathrm{~nm}$ ) was used to detect FITC-conjugated MAblabelled (oo)cysts and a UV filter block was used for DAPI (excitation, $350 \mathrm{~nm}$; emission, $450 \mathrm{~nm}$ ). The microorganism identification was based on their morphology, fluorescence, and size [29]. The number of (oo)cysts was calculated/100 mL for influent samples, effluent samples, sewage canal samples, and surface water samples and $100 \mathrm{~g}$ for soil and vegetable samples.

The collected data were used to quantify the level of contamination of Cryptosporidium and Giardia (oo)cysts in environmental samples. Based on this information, the concentration of oo(cysts) was calculated according to an equation referenced from Adeyemo et al. in 2019 [30].

$$
\text { Concentration }((\text { oo }) \text { cysts per } 100 \mathrm{~mL})=\frac{\mathrm{N}}{\mathrm{V}}
$$

where $\mathrm{N}$ is the number of (oo)cysts detected and $\mathrm{V}$ is the volume of processed sample $(100 \mathrm{~mL}$ or $100 \mathrm{~g})$.

\subsection{Statistical Analysis}

Statistical analysis was performed using STATA/MP software version 16.0 (StataCorp LLC, College Station, TX, USA). Both descriptive and inferential statistics were used. Descriptive statistics were performed on qualitative variables (frequency and percentage value calculations) and quantitative variables (median, min, and max value calculations). Inferential statistics of the Pearson Chi-Square test and Fisher's Exact test were applied where appropriate to compare the differences of social characteristics of the study population and the practices of biogas wastewater management by farmers in Bac Giang. Differences were set as statistically significant at a probability level of $p<0.05$.

\section{Results and Discussion}

The analysis of food and environmental samples for parasites of public health significance, including Cryptosporidium and Giardia, has been the subject of several previous studies $[2,10,31]$ and our survey contributes further data. In the present study, a total of 
239 samples were collected from different types of samples in the studied districts in Bac Giang province in 2020 (Figures 1 and 4; Table 1) via direct immunofluorescent detection to study the occurrence of Cryptosporidium spp. and Giardia spp. (oo)cysts. Among the samples, 19 were Cryptosporidium positive, and 40 were Giardia positive. The percentages of positive detection were $7.9 \%$ (95\% CI: 4.5-11.4) (19/239) and 16.7\% (95\% CI: $12.0-21.5)$ (40/239), respectively. In detail, the results indicated that the percentages of positive detection of Cryptosporidium spp. and Giardia spp. in influent, effluent, sewage canal, and vegetables were $13.1 \%(11 / 84), 6.0 \%(5 / 83), 15.4 \%(2 / 13)$ and $5.9 \%(1 / 17)$ and $26.2 \%$ $(22 / 84), 7.2 \%(6 / 83), 7.7 \%(1 / 13)$ and 5.9\% (1/17), respectively. Cryptosporidium and Giardia (oo)cysts were not detected in lake/pond water and soil samples. The results indicate that these environmental materials are contaminated with Cryptosporidium and Giardia (oo)cysts, and thus can act as a contamination source for human and animal infections in the area. The variation in occurrence of (oo)cysts was examined in different sampling locations before and after biogas plants. The results confirmed that Cryptosporidium spp. and Giardia spp. (oo)cysts are the most common in $11(13.1 \%)$ vs. $22(26.2 \%)$ influent samples followed by $5(6.0 \%)$ vs. 16 (19.3\%) effluents, as presented in Figure 4. Cryptosporidium spp. were more commonly found in sewage canals, while Giardia spp. were more prevalent in biogas influent and effluent samples. However, the prevalence of Giardia spp. decreased gradually depending on the proximity of biogas plant. Significantly more Giardia cysts were detected than Cryptosporidium oocysts in our survey of biogas influent and effluent samples, which has been also indicated by clinical observations where giardiasis is more frequently reported than cryptosporidiosis [32,33]. In 2014, the same research approach was carried out by Kitajima et al. [34] in Arizona (USA), whose aim was to detect Giardia and Cryptosporidium in the influent and effluent of two WWTPs (activated sludge systems). In this case, Giardia was more abundant than Cryptosporidium in about 1-2 log for both influent and effluent. The greater detection of Giardia cysts may be due to the infection intensity, zoonotic infection or other host-parasite, environmental factors, and hydrophobic tendency [35].

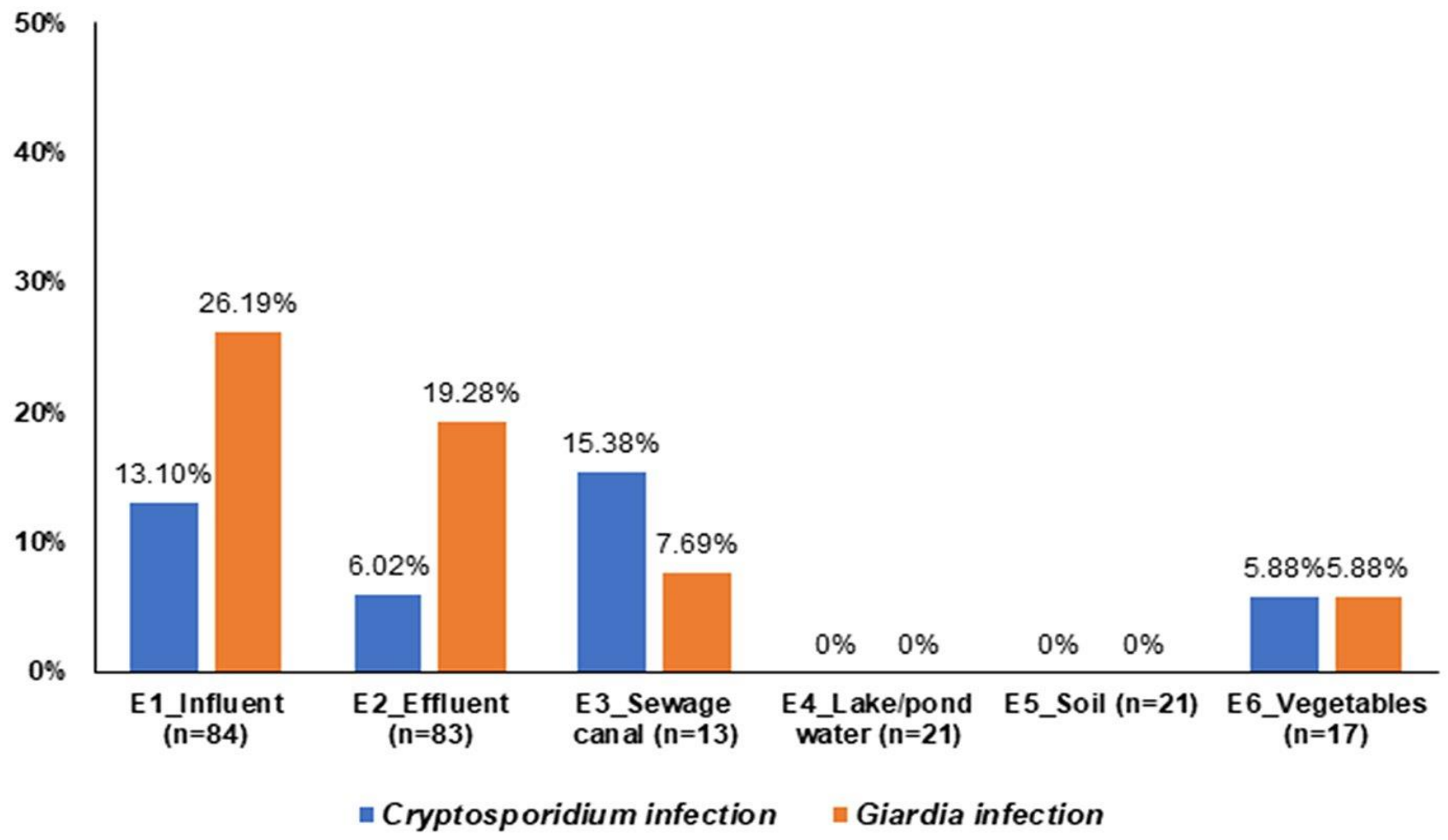

Figure 4. Variation of prevalence of Cryptosporidium and Giardia (oo)cysts in different sampling locations derived from the biogas system in Bac Giang province. 
Table 1. Occurrence and concentration of Giardia spp. cysts and Cryptosporidium spp. oocysts/100 mL of biogas influents, effluents, sewage canal samples, and $100 \mathrm{~g}$ of vegetables by district.

\begin{tabular}{|c|c|c|c|c|c|c|}
\hline \multirow{2}{*}{$\begin{array}{c}\text { Area/ } \\
\text { (n= Number of Samples) } \\
\text { Pathogen } \\
\text { Type of Sample }\end{array}$} & \multicolumn{2}{|c|}{$\begin{array}{l}\text { Lang Giang } \\
\quad(N=135)\end{array}$} & \multicolumn{2}{|c|}{$\begin{array}{l}\text { Viet Yen } \\
(\mathrm{N}=172)\end{array}$} & \multicolumn{2}{|c|}{$\begin{array}{c}\text { Hiep Hoa } \\
(\mathrm{N}=87)\end{array}$} \\
\hline & Giardia spp. & $\begin{array}{c}\text { Cryptosporidium } \\
\text { spp. }\end{array}$ & Giardia spp. & $\begin{array}{l}\text { Cryptosporidium } \\
\text { spp. }\end{array}$ & Giardia spp. & $\begin{array}{l}\text { Cryptosporidium } \\
\text { spp. }\end{array}$ \\
\hline $\begin{array}{l}\text { Influent }(\mathrm{E} 1, \mathrm{n}=84) \\
\text { Positive sample/examined }(\%) \\
\text { Median number of parasites } \\
\text { Min-Max a }\end{array}$ & $\begin{array}{c}2 / 11(18.8) \\
2.55 \times 10^{5} \\
1 \times 10^{4}-5 \times 10^{5}\end{array}$ & $\begin{array}{c}1 / 11(9.1) \\
3 \times 10^{5} \\
3 \times 10^{5}-3 \times 10^{5}\end{array}$ & $\begin{array}{c}14 / 57(24.6) \\
1 \times 10^{4} \\
1 \times 10^{4}-2 \times 10^{6}\end{array}$ & $\begin{array}{c}9 / 57(15.8) \\
2 \times 10^{4} \\
1 \times 10^{4}-1.4 \times 10^{5}\end{array}$ & $\begin{array}{c}6 / 16(37.5) \\
1.75 \times 10^{5} \\
1 \times 10^{4}-4.1 \times 10^{4}\end{array}$ & $\begin{array}{c}1 / 16(6.3) \\
2 \times 10^{5} \\
2 \times 10^{5}-2 \times 10^{5}\end{array}$ \\
\hline $\begin{array}{l}\text { Effluent }(\mathrm{E} 2, \mathrm{n}=83) \\
\text { Positive sample/examined }(\%) \\
\text { Median number of parasites } \\
\text { Min-Max }^{\text {a }}\end{array}$ & ND & $\begin{array}{c}1 / 11(9.1) \\
2 \times 10^{5} \\
2 \times 10^{5}-2 \times 10^{5}\end{array}$ & $\begin{array}{c}11 / 56(19.6) \\
2 \times 10^{5} \\
1 \times 10^{4}-8 \times 10^{4}\end{array}$ & ND & $\begin{array}{c}5 / 16(31.3) \\
1 \times 10^{5} \\
4 \times 10^{4}-5.5 \times 10^{5}\end{array}$ & $\begin{array}{c}4 / 16(25.0) \\
1.5 \times 10^{4} \\
1 \times 10^{4}-2 \times 10^{4}\end{array}$ \\
\hline $\begin{array}{l}\text { Sewage canal }(\mathrm{E} 3, \mathrm{n}=13) \\
\text { Positive sample/examined }(\%) \\
\text { Median number of parasites } \\
\text { Min-Max a }\end{array}$ & ND & ND & $\begin{array}{c}1 / 11(9.1) \\
1 \times 10^{4} \\
1 \times 10^{4}-1 \times 10^{4}\end{array}$ & $\begin{array}{c}2 / 11(18.2) \\
1 \times 10^{4} \\
1 \times 10^{4}-1 \times 10^{4}\end{array}$ & ND & ND \\
\hline $\begin{array}{l}\text { Vegetables }(\mathrm{E} 6, \mathrm{n}=17) \\
\text { Positive sample/examined }(\%) \\
\text { Median number of parasites } \\
\text { Min-Max a }\end{array}$ & ND & ND & $\begin{array}{c}1 / 17(5.9) \\
1 \times 10^{4} \\
1 \times 10^{4}-1 \times 10^{4}\end{array}$ & $\begin{array}{c}1 / 17(7.1) \\
2 \times 10^{4} \\
2 \times 10^{4}-2 \times 10^{4}\end{array}$ & ND & ND \\
\hline
\end{tabular}

a The median values were calculated based on the number of positive samples. Note: ND—not detected.

The concentrations of Giardia spp. cysts and Cryptosporidium spp. oocysts in the samples of biogas influents, effluents, sewage canals receiving biogas wastewater, and vegetables in all three districts are presented in Table 1. Of note, Giardia spp. cyst concentration varied from $1 \times 10^{4}$ to $2 \times 10^{6}$ cysts $/ 100 \mathrm{~mL}$ of biogas influent and from 'not detected' to $5.5 \times 10^{4}$ cysts $/ 100 \mathrm{~mL}$ of biogas effluent. Cryptosporidium spp. oocyst concentration varied from $1 \times 10^{4}$ to $3 \times 10^{5}$ oocysts $/ 100 \mathrm{~mL}$ of biogas influent and from 'not detected' to $2 \times 10^{5}$ oocysts $/ 100 \mathrm{~mL}$ of biogas effluent. Both Giardia spp. cysts and Cryptosporidium spp. oocysts were found in lowest concentrations in sewage canals, varying from 'not detected' to $2 \times 10^{4}$ (oo)cysts $/ 100 \mathrm{~mL}$. Although the concentration of (oo)cysts was lower in effluents than in raw influents, effluents from biogas plants are still more commonly used in agriculture than raw influents and thus, may pose a potential health risk to animals and humans, especially in more sensitive populations, such as children, the elderly, and immunocompromised. Cryptosporidium and Giardia (oo)cysts are very resilient and may survive in water for months and in particular Cryptosporidium may survive for a long time. In 2014, Huong et al. [36] identified that more than $90 \%$ of pig farms in Vietnam used disinfectants, such as chloramine, iodine, and lime to clean and disinfect pig pens. It is unknown to what extent the use of disinfectants can affect the microbial populations. However, Cryptosporidium and Giardia (oo)cysts are well known to be very resistant to chemical disinfection [30]. As a result, even at low concentrations, these parasites are worrisome, due to the high observed risk of infection, as shown by Sato et al. in 2013 [37]. Several studies indicated that lake/pond water was found to harbor Cryptosporidium and Giardia (oo)cysts [38-40]. This is contrary to our presented results where we found that the frequency and counts of both Giardia and Cryptosporidium (oo)cysts were zero in the investigated samples of lakes/ponds and soils. This may be due to the low recovery of the (oo)cysts, which was potentially below the detection limit. The inability to detect frequency or counts below the detection limit is a recurrent issue when dealing with environmental samples and is caused by the low concentration of an agent in the environment or low recovery of the applied methodology due to the various factors influencing the samples and methodology quality [30]. Although the obtained concentrations of these parasites were low or under the detection limit, their prevalence is high in the global population $[9,41]$, as these protozoan parasites are responsible for several outbreaks worldwide [5-7]. In a study on the use of tubular digesters to treat livestock waste, it was found that $C$. parvum posed a greater 
risk than G. lamblia in all of the exposure pathways (fomite, soil, and crop contamination from runoff) due to livestock shedding higher loads of Cryptosporidium oocysts and lower inactivation rates of Cryptosporidium oocysts during anaerobic digestion in comparison to G. lamblia cysts [41]. The risk of infection from exposure to contaminated soil and crops was significantly lower for a community using tubular digesters to treat livestock waste compared to a community where the untreated waste was applied to soil [42]. With the increased awareness of protozoan disease outbreaks, more attention should be paid in the future to the mitigation of risks associated with protozoa that emerged from biogas waste.

Vegetables are important in the consumer's dietary habit in almost all countries. It has been indicated that protozoan contamination of foods of plant origin may constitute a potential health hazard if these kinds of foods, which are normally consumed with minimal process, are ready to eat vegetables or raw and salads prepared in poor hygiene practices $[43,44]$. Regarding the limitation of water resort, the reuse of treated/untreated wastewater to irrigate farmlands has been highlighted [45]. However, the use of untreated wastewater or biogas effluents as a fertilizer for different crops is the main source of contamination as the demand for vegetables and fruits increases [46-48]. In our study, both Cryptosporidium and Giardia (oo)cysts were found in lowest concentration varying from 'not detected' to $2.10^{4}$ (oo)cysts/100 g with prevalence of $7.1 \%(1 / 17)$ vs. $5.9 \%(1 / 17)$ in vegetables. In a systematic review and meta-analysis conducted by Karshima in 2018 [49], Cryptosporidium was thought to be the most prevalent parasite from fruits and vegetables in Nigeria. Utaaker et al. in 2017a [50] identified that Cryptosporidium and Giardia (oo)cysts are among $6 \%(17 / 284)$ and 5\% (13/284) of vegetable samples in India. Alemu et al. in 2019 [51] reported the presence of Cryptosporidium and Giardia in 5.8\% and $6.9 \%$ of 347 vegetable samples collected from markets in southern Ethiopia. In a study performed by Eraky et al. in 2014 [52] in Egypt, from 530 vegetable samples, Giardia with the prevalence rate of 8.8\% was the most prevalent parasite detected from the samples. In China, the study of $642 \mathrm{mar}-$ ket vegetables indicated that Cryptosporidium spp. was responsible for $16(2.5 \%)$, while Giardia spp. accounted for 73 (14\%) [47,53]. Moreover, Utaaker et al. in 2017b [54] reported that Cryptosporidium and Giardia could remain viable on lettuce leaves and increased the chance of contamination in consumers. Therefore, in addition to increasing the irrigation of farms using raw wastewater, the risk of parasitic contamination can be increased.

In this study, few numbers were of farmers connected their toilet to the biogas unit. This was mainly due to the fact that the flush toilet had already been installed before the installation of biogas units. However, open sewage canals next to biogas units were receiving both biogas wastewater and flush toilet wastewater. These wastewater sources were used as a fertilizer for different crops. More farmers in Lang Giang (19.3\%) used this wastewater for vegetables eaten raw in comparison to farmers in Hiep Hoa (9.2\%), respectively. It appears from the interviews that biogas wastewater was mainly used to fertilize fruit trees with 37\% in Lang Giang, 25.6\% in Viet Yen, and 20.9\% in Hiep Hoa. In 2010, Rzeżutka et al. [55] analyzed the presence of oocysts of Cryptosporidium in vegetables grown in areas with moderate to high livestock production and claimed that close contact between vegetable farms and animal husbandry may enhance the risk of contamination of vegetables. This is of concern in Lang Giang, Hiep Hoa, and Viet Yen districts, where the main source of irrigation water in these areas is surface water bodies or biogas effluents, which can bring Cryptosporidium and Giardia (oo)cysts from faeces of humans and livestock to downstream vegetable farmlands. Cryptosporidium and Giardia (oo)cysts are buried with animal faeces and can be distributed to vegetable farmlands. In addition, they can remain infective for a long time due to their resistant wall [50]. Furthermore, due to the large livestock development in these regions, manure as human and animal product, played a critical role in fertilizing the farmlands.

There are studies indicating the insufficiency of the routine treatment processes used in WWTPs for the removal of all (oo)cysts of Cryptosporidium and Giardia [9,56-58]. In 2013, a study published by Sroka et al. [59] showed that the numbers of viable (oo)cysts of parasites are not reduced during the treatment process. In this study, a research for the main 
treatment method for raw livestock manure in rural communities, was carried out at biogas plants. Most of the biogas plants in Bac Giang were installed in a period of 5-10 years. They have an average volume of 13 cubic meters. All of the households, predominantly those with small-medium scale pig farms (10-50 pigs) used pig manure in their biogas plant. Poultry was also raised on a medium scale with less than 100 chickens per farm and very few households discharged poultry manure to the biogas plants (Table 2). Nearly all of the farmers acknowledged that the installation of the biogas system had direct benefits on the daily lives of poor farming households. Most importantly, it allowed for cleaner kitchens and reduced indoor air pollution. However, strong bad odors associated with pig manure were particularly seen as a nuisance to the household members and neighbors. As observed in this study, strong bad odors were due to the insufficient treatment of biogas plants. More specifically, insufficient treatment refers to the following: (1) No maintenance was carried out during their usage; (2) infrequent cleaning of biogas plants, with $30.4 \%$ of farmers in Lang Giang, 27.9\% of farmers in Viet Yen, and 45.9\% of farmers in Hiep Hoa; and (3) over usage of biogas plant capacity. Using personal protective measures when handling biogas wastewater was prevalent (40-65\%) in the interviewed participants (Table 3). Amongst the interviewed individuals, 30-60\% reported wearing a face mask, $40-70 \%$ reported wearing a boost, and $40-60 \%$ wore gloves and washed their hands with soap. Only $10 \%$ of the participants always used all four of the aforementioned personal protective measures when handling biogas wastewater while cleaning biogas plants or performing agricultural activities. It is unfortunate that our study did not measure the association between health risk and the use of protective measures while participating in activities exposed to biogas plants. However, in 2006, Trang do et al. [18] indicated that poor sanitation and hygiene practices and the lack of use of protective measures are important independent risk factors for helminth infections in Vietnam. In addition, a higher risk of diarrhea was found among people with inadequate use of protective measures in a study on the practices of farmers in agriculture activities in Hanam [60]. Moreover, the cleaning of a biogas plant is considered an exposure event, especially for farmers, who may not be wearing appropriate protective equipment. There is a need to raise awareness on protective measures in order to minimize potentially negative consequences for public health.

Table 2. Characteristics of the study population in Bac Giang province, Vietnam.

\begin{tabular}{|c|c|c|c|c|}
\hline Characteristics & Lạng Giang & Viet Yen & Hiep Hoa & \\
\hline & $\mathbf{N}=135$ & $\mathbf{N}=172$ & $\mathbf{N}=87$ & $p$-Value \\
\hline $\begin{array}{l}\text { Area used for agriculture } \\
\qquad\left(1000-3000 \mathrm{~m}^{2}\right)\end{array}$ & $112(84.2 \%)$ & $96(61.9 \%)$ & $47(55.3 \%)$ & $<0.001^{\mathrm{a}}$ \\
\hline Age group (41-54 years old) & $65(48.1 \%)$ & $77(44.8 \%)$ & $45(51.7 \%)$ & $0.56^{\mathrm{a}}$ \\
\hline Males & $107(79.3 \%)$ & $133(77.3 \%)$ & $66(75.9 \%)$ & $0.83^{a}$ \\
\hline High education level & $1(0.7 \%)$ & $2(1.2 \%)$ & $2(2.3 \%)$ & $0.22^{b}$ \\
\hline Farmer & $134(99.3 \%)$ & $169(98.3 \%)$ & $84(96.6 \%)$ & $0.18^{b}$ \\
\hline Size of the household ( $\geq 5$ people) & $72(53.3 \%)$ & $91(52.9 \%)$ & $49(56.3 \%)$ & $0.87^{\mathrm{a}}$ \\
\hline No. of pigs raised & & & & $<0.001^{\mathrm{a}}$ \\
\hline$<10$ pigs & $65(48.2 \%)$ & $35(20.4 \%)$ & $18(20.7 \%)$ & \\
\hline $10-50$ pigs & $58(43.0 \%)$ & $121(70.4 \%)$ & $59(67.8 \%)$ & \\
\hline$>50$ pigs & $12(8.9 \%)$ & $16(9.3 \%)$ & $10(11.5 \%)$ & \\
\hline No. of poultry raised & & & & $<0.001^{a}$ \\
\hline No poultry & $5(3.7 \%)$ & $17(9.9 \%)$ & $6(6.9 \%)$ & \\
\hline$<100$ & $117(86.7 \%)$ & $140(81.4 \%)$ & $59(67.8 \%)$ & \\
\hline $100-200$ & $9(6.7 \%)$ & $10(5.8 \%)$ & $8(9.2 \%)$ & \\
\hline$>200$ & $4(2.9 \%)$ & $5(2.9 \%)$ & $14(16.1 \%)$ & \\
\hline
\end{tabular}

${ }^{\mathrm{a}} p$-value based on the Pearson Chi-Square test. ${ }^{\mathrm{b}} p$-value based on Fisher's Exact test. 
Table 3. Practices of biogas wastewater management by farmers in Bac Giang, Vietnam.

\begin{tabular}{|c|c|c|c|c|}
\hline & Lang Giang & Viet Yen & Hiep Hoa & \\
\hline & $\mathbf{N}=135$ & $\mathbf{N}=172$ & $\mathbf{N}=87$ & $p$-Value \\
\hline $5-10$ years of age of biogas plant & $72(53.3 \%)$ & $106(61.6 \%)$ & $48(55.2 \%)$ & $0.002^{\mathrm{a}}$ \\
\hline Clean-up of biogas plant & $41(30.4 \%)$ & $48(27.9 \%)$ & $40(45.9 \%)$ & $0.011^{\mathrm{a}}$ \\
\hline No repair of biogas plant & $126(93.3 \%)$ & $168(98.2 \%)$ & $85(97.7 \%)$ & $0.08^{\mathrm{b}}$ \\
\hline Pig manure used for biogas plant & $134(99.3 \%)$ & $170(98.8 \%)$ & $87(100 \%)$ & $0.80^{\mathrm{b}}$ \\
\hline Poultry manure used for biogas plant & $1(0.7 \%)$ & $3(1.7 \%)$ & $0(0 \%)$ & $0.55^{\mathrm{b}}$ \\
\hline Possible opened effluent tank & $123(91.1 \%)$ & $142(83.0 \%)$ & $83(95.4 \%)$ & $0.002^{b}$ \\
\hline Household involved in effluent tank cleaning & $29(21.5 \%)$ & $36(20.9 \%)$ & $20(22.9 \%)$ & $0.25^{b}$ \\
\hline $\begin{array}{l}\text { Household involved in sewage canal cleaning } \\
\text { Personal protective measures }\end{array}$ & $72(53.3 \%)$ & $80(46.5 \%)$ & $37(42.5 \%)$ & $0.26^{\mathrm{a}}$ \\
\hline Wearing face mask & $48(62.3 \%)$ & $30(31.3 \%)$ & $21(45.7 \%)$ & $<0.001^{b}$ \\
\hline Wearing boost & $50(64.9 \%)$ & $35(37.2 \%)$ & $22(47.8 \%)$ & $<0.001^{b}$ \\
\hline Wearing gloves & $42(54.6 \%)$ & $29(31.5 \%)$ & $18(39.1 \%)$ & $0.001^{\mathrm{a}}$ \\
\hline Washing hands with soap & $43(56.6 \%)$ & $33(34.4 \%)$ & $18(39.1 \%)$ & $<0.001^{a}$ \\
\hline \multicolumn{5}{|l|}{ Use of biogas wastewater } \\
\hline Fertilizer of corns & $27(20.0 \%)$ & $22(12.8 \%)$ & $6(6.9 \%)$ & $0.052^{b}$ \\
\hline Fertilizer of fruit tree & $50(37.0 \%)$ & $44(25.6 \%)$ & $18(20.9 \%)$ & $0.025^{b}$ \\
\hline Fertilizer of vegetables & $26(19.3 \%)$ & $23(13.5 \%)$ & $8(9.2 \%)$ & $0.12^{b}$ \\
\hline
\end{tabular}

${ }^{\mathrm{a}} p$-value based on the Pearson Chi-Square test. ${ }^{\mathrm{b}} p$-value based on Fisher's Exact test.

\section{Conclusions}

In the present study, the results revealed the occurrence of Cryptosporidium and Giardia in biogas waste and their presence in vegetables in Bac Giang, Vietnam. In addition, the study emphasized the importance of effective management of livestock manure by biogas plants in Vietnam.

The limitation of this study was the lack of molecular characterization of the identified (oo)cysts since the public health importance and clinical significance of the parasites depend on the specific species, genotypes, and their viability or infectivity to cause human infection.

Further actions to improve the quality of biogas effluents are required as the pathogenic species of Cryptosporidium and Giardia (oo)cysts can result in potential risk for zoonotic and anthroponotic transmission. This is due to the exposure to biogas waste or contamination of food of plant origin, in the case that these kinds of food are normally consumed raw or with minimal processing.

Moreover, there is a need for the education of local governments and health authorities by offering them the possibility to understand the health risks associated with the exposure to biogas wastewater and to undertake control measures.

Furthermore, it is imperative that these technologies have the ability to reduce the contamination of water and food sources by these two pathogenic protozoa and thus, protect the health of animals and humans in the context of One Health concept.

Author Contributions: Conceptualization and methodology, N.T.T., P.K. and P.D.P.; investigation, N.T.T., T.T.N., L.T.T., H.T.T.H. and T.Q.C.; statistical analysis: P.D.P. and N.H.P.; writing-original draft preparation, N.T.T., P.D.P. and P.K.; writing-review and editing, N.T.T., P.D.C., P.D.P. and P.K.; supervision, P.K. All authors have read and agreed to the published version of the manuscript.

Funding: This research received funding from the Vietnam National Foundation for Science and Technology Development (NAFOSTED) under Grant No: 108.04-2018.09.

Institutional Review Board Statement: Ethical clearance for the study was provided by the Institutional Review Board in Biomedical Research of the National Institute of Hygiene and Epidemiology in Hanoi (IRB-VN01057/IORG 0008555) under the number: NIHE IRB-09/2019.

Informed Consent Statement: People participated in the study after informed consent.

Data Availability Statement: Not applicable.

Acknowledgments: The authors acknowledge all of the farmers at the Hiep Hoa, Lang Giang, Viet Yen districts in Bac Giang province. The authors also acknowledge Bac Giang Sub-Department of 
Veterinary and Husbandry for their assistance with this research. In particular, we thank Vu Van Tu, Nguyen Thanh Luong, Phung Thi Thu Hang, and Le Huy Hoang for their great inputs to the study.

Conflicts of Interest: The authors declare no conflict of interest.

\section{References}

1. Ecology and Environment Institute. Study and Analysis of Biogas Development in Some Northern Provinces and Its Contribution to Preparations for the Implementation of Vietnam's NDC; Vietnam-Deliverable-1-Biogas-FINAL; Facilitating Implementation and Readiness for Mitigation Project (FIRM): Hanoi, Vietnam, 2017.

2. Amorós, I.; Moreno, Y.; Reyes, M.; Moreno-Mesonero, L.; Alonso, J.L. Prevalence of Cryptosporidium oocysts and Giardia cysts in raw and treated sewage sludges. Environ. Technol. 2016, 37, 2898-2904. [CrossRef] [PubMed]

3. Tonani, K.A.; Padula, J.A.; Julião, F.C.; Fregonesi, B.M.; Alves, R.I.; Sampaio, C.F.; Beda, C.F.; Hachich, E.M.; Segura-Muñoz, S.I. Persistence of Giardia, Cryptosporidium, Rotavirus, and Adenovirus in treated sewage in São Paulo state. Eur. J. Epidemiol. 2013, 99, 1144-1147.

4. Schlosser, O.; Grall, D.; Laurenceau, M.N. Intestinal parasite carriage in workers exposed to sewage. Eur. J. Epidemiol. 1999, 15, $261-265$. [CrossRef] [PubMed]

5. Ahmed, S.A.; Karanis, P. Cryptosporidium and Cryptosporidiosis: The Perspective from the Gulf Countries. Int. J. Environ. Res. Public Health 2020, 17, 6824. [CrossRef]

6. Baldursson, S.; Karanis, P. Waterborne transmission of protozoan parasites: Review of worldwide outbreaks-An update 2004-2010. Water Res. 2011, 45, 6603-6614. [CrossRef]

7. Efstratiou, A.; Ongerth, J.E.; Karanis, P. Waterborne transmission of protozoan parasites: Review of worldwide outbreaks-An update 2011-2016. Water Res. 2017, 114, 14-22. [CrossRef]

8. Karanis, P.; Kourenti, C.; Smith, H. Waterborne transmission of protozoan parasites: A worldwide review of outbreaks and lessons learnt. J. Water Health 2007, 5, 1-38. [CrossRef]

9. Rosado-García, F.M.; Guerrero-Flórez, M.; Karanis, G.; Hinojosa, M.D.C.; Karanis, P. Water-borne protozoa parasites: The Latin American perspective. Int. J. Hyg. Environ. Health 2017, 220, 783-798. [CrossRef]

10. Razzolini, M.T.P.; Breternitz, B.S.; Kuchkarian, B.; Bastos, V.K. Cryptosporidium and Giardia in urban wastewater: A challenge to overcome. Environ. Pollut. 2020, 257, 113545. [CrossRef]

11. Graczyk, T.K.; Lucy, F.E.; Tamang, L.; Miraflor, A. Human enteropathogen load in activated sewage sludge and corresponding sewage sludge end products. Appl. Environ. Microbiol. 2007, 73, 2013-2015. [CrossRef]

12. Khouja, L.B.; Cama, V.; Xiao, L. Parasitic contamination in wastewater and sludge samples in Tunisia using three different detection techniques. Parasitol. Res. 2010, 107, 109-116. [CrossRef] [PubMed]

13. Van Frankenhuyzen, J.K.; Trevors, J.T.; Lee, H.; Flemming, C.A.; Habash, M.B. Molecular pathogen detection in biosolids with a focus on quantitative PCR using propidium monoazide for viable cell enumeration. J. Microbiol. Methods 2011, 87, 263-272. [CrossRef] [PubMed]

14. Spanakos, G.; Biba, A.; Mavridou, A.; Karanis, P. Occurrence of Cryptosporidium and Giardia in recycled waters used for irrigation and first description of Cryptosporidium parvum and C. muris in Greece. Parasitol. Res. 2015, 114, 1803-1810. [CrossRef] [PubMed]

15. Chauret, C.; Springthorpe, S.; Sattar, S. Fate of Cryptosporidium oocysts, Giardia cysts, and microbial indicators during wastewater treatment and anaerobic sludge digestion. Can. J. Microbiol. 1999, 45, 257-262. [CrossRef] [PubMed]

16. Ongerth, J.E.; Plutzer, J.; Karanis, P. Cryptosporidium and Giardia-Levels and distribution in surface water throughout Europe. Proceed 2018, 2, 690. [CrossRef]

17. Vu, T.K.V.; Tran, M.T.; Dang, T.T.S. A survey of manure management on pig farms in Northern Vietnam. Livest. Sci. 2007, 112, 288-297. [CrossRef]

18. Trang, D.T.; van der Hoek, W.; Cam, P.D.; Vinh, K.T.; Hoa, N.V.; Dalsgaard, A. Low risk for helminth infection in wastewater-fed rice cultivation in Vietnam. J. Water Health 2006, 4, 321-331. [CrossRef] [PubMed]

19. Nguyen, T.T.; Traub, R.; Pham, P.D.; Nguyen, H.V.; Nguyen, K.C.; Phung, C.D.; Dalsgaard, A. Prevalence and molecular characterization of Cryptosporidum spp. and Giardia spp. in environmental samples in Hanam province, Vietnam. Food Waterborne Parasitol. 2016, 3, 13-20. [CrossRef]

20. Tram, N.T.; Dalsgaard, A. Water used to moisten vegetables is a source of Escherichia coli and protozoan parasite contamination at markets in Hanoi, Vietnam. J. Water Health 2014, 12, 896-900. [CrossRef]

21. Le-Thi, T.; Pham-Duc, P.; Zurbrügg, C.; Luu-Quoc, T.; Nguyen-Mai, H.; Vu-Van, T.; Nguyen-Viet, H. Diarrhea risks by exposure to livestock waste in Vietnam using quantitative microbial risk assessment. Int. J. Public Health 2017, 62 (Suppl. S1), 83-91. [CrossRef]

22. Bodhidatta, L.; Lan, N.T.; Hien, B.T.; Lai, N.V.; Srijan, A.; Serichantalergs, O.; Fukuda, C.D.; Cam, P.D.; Mason, C.J. Rotavirus disease in young children from Hanoi, Vietnam. Pediatr. Infect. Dis. J. 2007, 26, 325-328. [CrossRef] [PubMed]

23. Ngan, P.K.; Khanh, N.G.; Tuong, C.V.; Quy, P.P.; Anh, D.N.; Thuy, H.T. Persistent diarrhea in Vietnamese children: A preliminary report. Acta Paediatr. 1992, 81, 124-126. [CrossRef] [PubMed] 
24. Uga, S.; Hoa, N.T.; Thuan, L.K.; Noda, S.; Fujimaki, Y. Intestinal parasitic infections in schoolchildren in a suburban area of Hanoi, Vietnam. Southeast Asian J. Trop. Med. Public Health 2005, 36, 1407-1411.

25. Gatei, W.; Greensill, J.; Ashford, R.W.; Cuevas, L.E.; Parry, C.M.; Cunliffe, N.A.; Beeching, N.J.; Hart, C.A. Molecular analysis of the 18S rRNA gene of Cryptosporidium parasites from patients with or without human immunodeficiency virus infections living in Kenya, Malawi, Brazil, the United Kingdom, and Vietnam. J. Clin. Microbiol. 2003, 41, 1458-1462. [CrossRef]

26. Verle, P.; Kongs, A.; De, N.V.; Thieu, N.Q.; Depraetere, K.; Kim, H.T.; Dorny, P. Prevalence of intestinal parasitic infections in northern Vietnam. Trop. Med. Int. Health 2003, 8, 961-964. [CrossRef] [PubMed]

27. Iwashita, H.; Sugamoto, T.; Takemura, T.; Tokizawa, A.; Vu, T.D.; Nguyen, T.H.; Pham, T.D.; Tran, N.L.; Doan, H.T.; Pham, A.H.Q.; et al. Molecular epidemiology of Giardia spp. in northern Vietnam: Potential transmission between animals and humans. Parasite Epidemiol. Control 2021, 12, e00193. [CrossRef]

28. Maddox-Hyttel, C.; Langkjær, R.B.; Enemark, H.L.; Vigre, H. Cryptosporidium and Giardia in different age groups of Danish cattle and pigs-Occurrence and management associated risk factors. Vet. Parasitol. 2006, 141, 48-59. [CrossRef]

29. Dos Santos Toledo, R.; Martin, F.D.C.; Freire, R.L. Waterborne Giardia and Cryptosporidium: Contamination of human drinking water by sewage and cattle faeces. Semin. Ciências Agrárias 2017, 38, 3395-3415. [CrossRef]

30. Adeyemo, F.E.; Singh, G.; Reddy, P.; Bux, F.; Stenström, T.A. Efficiency of chlorine and UV in the inactivation of Cryptosporidium and Giardia in wastewater. PLOS ONE 2019, 14, e0216040. [CrossRef]

31. Domenech, E.; Amorós, I.; Moreno, Y.; Alonso, J.L. Cryptosporidium and Giardia safety margin increase in leafy green vegetables irrigated with treated wastewater. Int. J. Hyg. Environ. Health 2018, 221, 112-119. [CrossRef]

32. Centers for Disease Control and Prevention. Cryptosporidiosis Surveillance-United States, 2006-2008. Surveillance Summaries MMWR 59; No. SS-6. 2010. Available online: https:/ / www.cdc.gov/mmwr/preview/mmwrhtml/ss5906a1.htm (accessed on 26 December 2021).

33. Centers for Disease Control and Prevention. Giardiasis Surveillance-United States, 2006-2008. Surveillance Summaries; MMWR 59; No. SS-6. 2010. Available online: https:/ / www.cdc.gov/mmwr/preview/mmwrhtml/ss5906a2.htm (accessed on 26 December 2021).

34. Kitajima, M.; Haramoto, E.; Iker, B.C.; Gerba, C.P. Occurrence of Cryptosporidium, Giardia, and Cyclospora in influent and effluent water at wastewater treatment plants in Arizona. Sci. Total Environ. 2014, 484, 129-136. [CrossRef] [PubMed]

35. Dumètre, A.; Aubert, D.; Puech, P.H.; Hohweyer, J.; Azas, N.; Villena, I. Interaction forces drive the environmental transmission of pathogenic protozoa. Appl. Environ. Microbiol. 2012, 78, 905-912. [CrossRef] [PubMed]

36. Huong, L.Q.; Madsen, H.; Anh, L.X.; Ngoc, P.T.; Dalsgaard, A. Hygienic aspects of livestock manure management and biogas systems operated by small-scale pig farmers in Vietnam. Sci. Total Environ. 2014, 470-471, 53-57. [CrossRef] [PubMed]

37. Sato, M.I.; Galvani, A.T.; Padula, J.A.; Nardocci, A.C.; de Lauretto Souza, M.; Razzolini, M.T.; Hachich, E.M. Assessing the infection risk of Giardia and Cryptosporidium in public drinking water delivered by surface water systems in Sao Paulo State, Brazil. Sci. Total Environ. 2013, 442, 389-396. [CrossRef] [PubMed]

38. Lim, Y.A.; Ramasame, S.D.; Mahdy, M.A.; Sulaiman, W.Y.; Smith, H.V. Detection and molecular characterization of Giardia isolated from recreational lake water in Malaysia. Parasitol. Res. 2009, 106, 289-291. [CrossRef] [PubMed]

39. Coupe, S.; Delabre, K.; Pouillot, R.; Houdart, S.; Santillana-Hayat, M.; Derouin, F. Detection of Cryptosporidium, Giardia and Enterocytozoon bieneusi in surface water, including recreational areas: A one-year prospective study. FEMS Immunol. Med. Microbiol. 2006, 47, 351-359. [CrossRef] [PubMed]

40. Imre, K.; Morar, A.; Ilie, M.S.; Plutzer, J.; Imre, M.; Emil, T.; Herbei, M.V.; Dărăbus, G. Survey of the Occurrence and Human Infective Potential of Giardia duodenalis and Cryptosporidium spp. in Wastewater and Different Surface Water Sources of Western Romania. Vector-Borne Zoonotic Dis. 2017, 17, 685-691. [CrossRef]

41. Balderrama-Carmona, A.P.; Gortáres-Moroyoqui, P.; Álvarez-Valencia, L.H.; Castro-Espinoza, L.; Balderas-Cortés, J.D.J.; MondacaFernández, I.; Chaidez-Quiroz, C.; Meza-Montenegro, M.M. Quantitative microbial risk assessment of Cryptosporidium and Giardia in well water from a native community of Mexico. Int. J. Environ. Health Res. 2015, 25, 570-582. [CrossRef]

42. Kinyua, M.N.; Wald, I.; Camacho-Céspedes, F.; Izurieta, R.; Haas, C.N.; Ergas, S.J. Does the use of tubular digesters to treat livestock waste lower the risk of infection from Cryptosporidium parvum and Giardia lamblia? J. Water Health 2016, 14, 738-753. [CrossRef]

43. Losio, M.N.; Pavoni, E.; Bilei, S.; Bertasi, B.; Bove, D.; Capuano, F.; Farneti, S.; Blasi, G.; Comin, D.; Cardamone, C.; et al. Microbiological survey of raw and ready-to-eat leafy green vegetables marketed in Italy. Int. J. Food Microbiol. 2015, $210,88-91$. [CrossRef]

44. Ryan, U.; Hijjawi, N.; Feng, Y.; Xiao, L. Giardia: An under-reported foodborne parasite. Int. J. Parasitol. 2019, 49, 1-11. [CrossRef] [PubMed]

45. Hachich, E.M.; Galvani, A.T.; Padula, J.A.; Stoppe, N.C.; Garcia, S.C.; Bonanno, V.M.; Barbosa, M.R.; Sato, M.I. Pathogenic parasites, and enteroviruses in wastewater: Support for a regulation on water reuse. Water Sci. Technol. 2013, 67, 1512-1518. [CrossRef] [PubMed]

46. Fuhrimann, S.; Winkler, M.S.; Kabatereine, N.B.; Tukahebwa, E.M.; Halage, A.A.; Rutebemberwa, E.; Medlicott, K.; Schindler, C.; Utzinger, J.; Cissé, G. Risk of intestinal parasitic infections in people with different exposures to wastewater and fecal sludge in Kampala, Uganda: A cross-sectional study. PLoS Negl. Trop. Dis. 2016, 10, e0004469. [CrossRef] [PubMed]

47. Maimon, A.; Tal, A.; Friedler, E.; Gross, A. Safe on-Site Reuse of greywater for irrigation-A critical review of current guidelines. Environ. Sci. Technol. 2010, 44, 3213-3220. [CrossRef] 
48. Troldborg, M.; Duckett, D.; Allan, R.; Hastings, E.; Hough, R.L. A risk-based approach for developing standards for irrigation with reclaimed water. Water Res. 2017, 126, 372-384. [CrossRef]

49. Karshima, S.N. Parasites of importance for human health on edible fruits and vegetables in Nigeria: A systematic review and meta-analysis of published data. Pathog. Glob. Health 2018, 112, 47-55. [CrossRef]

50. Utaaker, K.S.; Kumar, A.; Joshi, H.; Chaudhary, S.; Robertson, L.J. Checking the detail in retail: Occurrence of Cryptosporidium and Giardia on vegetables sold across different counters in Chandigarh, India. Int. J. Food Microbiol. 2017, 263, 1-8. [CrossRef]

51. Alemu, G.; Mama, M.; Misker, D.; Haftu, D. Parasitic contamination of vegetables marketed in Arba Minch town, southern Ethiopia. BMC Infect. Dis. 2019, 19, 410. [CrossRef]

52. Eraky, M.A.; Rashed, S.M.; Nasr, M.S.; El-Hamshary, A.M.; Salah El-Ghannam, A. Parasitic contamination of commonly consumed fresh leafy vegetables in Benha, Egypt. J. Parasitol. Res. 2014, 2014, 613960. [CrossRef]

53. Li, X.; Zhang, X.; Jian, Y.; Wang, G.; Ma, L.; Schou, C.; Karanis, P. Detection of Cryptosporidium oocysts and Giardia cysts in vegetables from street markets from the Qinghai Tibetan Plateau Area in China. Parasitol. Res. 2020, 119, 1847-1855. [CrossRef]

54. Utaaker, K.S.; Skjerve, E.; Robertson, L.J. Keeping it cool: Survival of Giardia cysts and Cryptosporidium oocysts on lettuce leaves. Int. J. Food Microbiol. 2017, 255, 51-57. [CrossRef] [PubMed]

55. Rzeżutka, A.; Nichols, R.A.B.; Connelly, L.; Kaupke, A.; Kozyra, I.; Cook, N.; Birrell, S.; Smith, H.V. Cryptosporidium oocysts on fresh produce from areas of high livestock production in Poland. Int. J. Parasitol. 2010, 139, 96-101. [CrossRef] [PubMed]

56. Aldeyarbi, H.M.; Abu El-Ezz, N.M.T.; Karanis, P. Cryptosporidium and cryptosporidiosis: The African perspective. Environ. Sci. Pollut. Res. 2016, 23, 13811-13821. [CrossRef] [PubMed]

57. Martins, F.D.C.; Ladeia, W.A.; Toledo, R.D.S.; Garcia, J.L.; Navarro, I.T.; Freire, R.L. Surveillance of Giardia and Cryptosporidium in sewage from an urban area in Brazil. Rev. Bras. Parasitol. Vet. 2019, 28, 291-297. [CrossRef] [PubMed]

58. Nasser, A.M.; Tweto, E.; Nitzan, Y. Die-off of Cryptosporidium parvum in soil and wastewater effluents. J. Appl. Microbiol. 2007, 102, 169-176. [CrossRef] [PubMed]

59. Sroka, J.; Stojecki, K.; Zdybel, J.; Karamon, J.; Cencek, T.; Dutkiewicz, J. Occurrence of Cryptosporidium oocysts and Giardia cysts in effluent from sewage treatment plant from eastern Poland. Ann. Agric. Environ. Med. 2013, 1, 57-62.

60. Pham-Duc, P.; Nguyen-Viet, H.; Hattendorf, J.; Cam, P.D.; Zurbrügg, C.; Zinsstag, J.; Odermatt, P. Diarrhoeal diseases among adult population in an agricultural community Hanam province, Vietnam, with high wastewater and excreta re-use. BMC Public Health 2014, 14, 978. [CrossRef] [PubMed] 